\title{
CRITICAL REVIEW BUKU “PENELITIAN HUKUM”PETER MAHMUD MARZUKI PENELITIAN HUKUM AD QUEMTENTANG NORMA
}

\author{
Agung Hidayat \\ Email: mazkuri.agung@gmail.com
}

\begin{abstract}
Absract--Ilmu hukum secara ontologis adalah ilmu yang objeknya norma. Norma adalah nilai-nilai yang tak kasat mata, tetapi dapat kita rasai. Ilmu hukum sui generis normatif. Begitu titik berdiri buku yang di-review ini dalam memandang apa itu hakikat ilmu hukum. Perkembangan hukum dewasa ini menempatkan norma hukum dengan diundangkan, dalam bentuk simbol-simbol gores: tulisan atau rumusan pasal-pasal. Namun begitu, bukan barisan kata-kata dalam pasal itu yang dimaksud norma hukum, melainkanyang instrinsik yang bisa kita tangkap dari membacai itu.Dalam ruang akademik dewasa ini, ada kerancuan paradigma/cara berpikir dalam kegiatan penelitian dan cara pendekatannya di kalangan para penstudi ilmu hukum yang mana mengadopsi metode ilmu sosial. Ini bias. Bukan metode ilmu sosial itu salah, melainkan keliru untuk diadopsi oleh penstudi ilmu hukum yang sui generis normatif. Meski dua rumpun keilmuan ini memiliki object materia sama, yaitu hukum, akan tetapi object forma keduanyalah yang membedakan bagaimana memandang dan memperlakukan object materia itu.Buku ini layak di-review karena "one in a million" di antara buku-buku bertema penelitian hukum yang beredar. Harapannya, pertama,review ini bisa memudahkan siapa saja yang tergerak membacai naskah buku dan, kedua,secara subjektif sebagai media menyampaikan beberapa catatankritis argumentatif atas penjelasan buku.
\end{abstract}

Keywords: book review, jurisprudence,law, legal research.

Satu ketika, di satu malam, saya bersua kawan di angkringan, meneguk kopi tubruk dan bercengkrama, ia baru saja wisuda dari salah satu fakultas ilmu hukum di Jogja. Entah kenapa, obrolan kemudian ber-geser pada pengalaman penyusunan tugas akhir. Apa yang diangkat dan apa metode yang diadopsi, begitu saya bertanya. Sejurus kemudian, saya dikirimisalinan softfiletugas akhirnya yang sudah dipertahankan dalam sidang, via aplikasi berkirim pesan. Saya bacai tepat di kursi angkringan berhadap-hadapan dengannya. Sampai di bagian metode, tepat-nya subjudul "Sumber Data”, menarik mem-bacainya.Dia mengutip pendapat (doctrine) Peter MahmudMarzuki dalam buku Penelitian Hukum Edisi Revisi-beliau sendiri tegas menolak istilah "data" dalam penelitian hukum (h. 6o)—dan ia sekaligus mengutipnaskah buku Penelitian Hukum Normatif-nya Soerjono Soekanto dan Sri Mamudji. Jika kita pelajari seksama dua buku tadi, cara pandang kedua tokohbertolak belakang terhadap hukum. Perbedaan cara pandang tentu berakibat pada cara atau metode/pendekatan pencarian kebenaran atau metode penelitian. Itu sudah pasti.

Menurut pemahaman Soerjono Soekanto dan Sri Mamudji, yang dimaksud "normatif" adalah kepustakaan ${ }^{1}$, perundang-undangan di-dudukkan sebagai bahan pustaka. Sedangkan membacai buku

\footnotetext{
${ }^{1}$ Soerjono Soekanto dan Sri Mamudji, 2017,Penelitian Hukum Normatif, RajaGrafindo Persada, Jakarta, h. 23; Lebih jauh, kepustakaan di sini menurut beliau berdua dapat kita pahamididudukkan sebagai dokumen laporan atas hasil penelitian lapangan/langsung. Yang diperoleh dan dikumpulkan dari lapangan langsung disebut data primer, periksa ibid, h. 12, h. 2325;Dapat dipahami, jika seseorang di lain waktu mengacu laporan itu sebagai acuan penelitian-nya, maka penelitian yang dikerjakan seseorang itu termasuk penelitian mengacu pada data sekunder. Membacai buku beliau lebih lanjut, data sekunder ini menurutnya dibagi lagi menjadi: bahan hukum primer, bahan hukum sekunder, dan bahan hukum tersier. Jika direnungkan, norma menurut Soekantodan Mamudji bukan bersifat abstrak dan bukan berkaitanvalues,tetapi sekedardokumen laporan dari hasil penelitian lapangan, cara pandang semacam ini adalah cara pandang ilmu sosial, yaitu meneliti/mengkaji hukum bukan sebagai 
yang di-review ini, utamanya bab pertama dan kedua yang mendedah ilmu hukum secara kefilsafatan, yang dimaksud normatif erat kaitannya dengan nilai-nilai (values), sesuatu yang sifatnya abstrak. Ilmu hukum dalam ruas filsafat keilmuan masuk dalam rumpun normologis.Bagaimana bisakita membenarkan 2 cara pandangberbeda dan mengutipnya secara bersamaan?

\section{Siapapenulis dan apaisi buku}

Buku Penelitian Hukum Edisi Revisi adalah karya Prof. Dr. Peter Mahmud Marzuki, S.H., M.H., LL.M., Guru Besar Ilmu Hukum Uni-versitas Airlangga. Karya beliau lainnya adalahPengantar Ilmu Hukum, An Introduction to Indonesian Law, dan yang terbaru ada Teori Hukum.Buku ini menarik direview karena, hemat pribadi, cara pandangnya terhadap hukumdan metode/pendekatan penelitiannya diametral terhadap pemahaman umum yang jamak berkembangdi ruang akademik hukum. Selain itu,tidak memakai bahasa yang berbelit dan muter-muterterhadap ketidaksetujuan pada cara pandang yang berbeda. Kelugasan adalah poin tersendiri buku ini, tentu ini attitudeakademisi yang tepat.Sudah seharus-nya.

Gambaran ringkas isi buku yang diterbit-kan oleh penerbit Kencana ini terdiri dari 6 bab.

Bab pertama, membicarakan hakikat ilmu hukum dan bagaimana pencarian kebenaran-nya (metode/pendekatan penelitian) yang tentu sajasudah pasti berbeda dengan disiplin ilmu lain karena objek yang dikaji (object materia) dan paradigma keilmuannya (object forma). Ilmu hukum ad quem tentang norma. Bab ini berisi pula kritik terhadap penelitian hukum yang jamak berkembang di Indonesia. Sepertinya, jika diraba, kritik diarahkan pada tren penelitian ranahpraktis hukum ${ }^{2}$ saat ini. Pendekatan "praktis hukum" tidak bisa tidak adalah kajian/penelitian sejauh dogmatik hukum. Alihalih memakai metode tepat sesuai paradigma keilmuan, sebaliknya,yang berkembang dalam penelitian praktis hukum justru menggunakan metode penelitian ilmu sosial. Penulis mengawali penjelasannya tentang hakikat hukum yang berbeda dengan ilmu sosial dengan menguraikan perbedaan antara sosiologi hukum (sociology of law) dengan sociological jurisprudence-nya Roscoe Pound. Oleh Paton,sociological jurisprudenceini diistilahkan functional school, 'mazhab fungsional', agar mudah dibedakan.Cara menarik oleh penulis untuk memberikan gambaran ke kepala kita tentang perbedaan ilmu hukum dan ilmu sosial (sosiologi), sekaligus menunjukkan perbedaan antara penelitian hukum dengan penelitian disiplin lainnya, terutama penelitian ilmu sosial. Bab ini juga menguraikan fungsi dan tujuan penelitian hukum yang sifatnya preskriptif, "hasil yang dicapai adalah untuk memberikan preskripsi mengenai apa yang seyogianya atas isu yang diajukan (h.83)".Caranya, mencari dan menemukan jawaban atas isu hukumke sumber hukumnya. Menguasaikonsep-konsep hukum dan format/sistem hukum serta fitur-fitur aturan yang berlaku adalah keniscayaan. Penelitian hukum pada dasarnya adalah usaha menyusun argumentasi hukum untuk isu hukum yang dihadapi dengan bertolakdari sumber hukumnya, yang mana sumber hukum yang diacu sendiri tergantung di lapisan mana isu hukumyang dihadapiitu terletak. Berbeda dengan ilmu sosial yang sifatnya deskriptif, sekedar membuat laporan faktual objekpenelitian apa adanyadan sebagaimana adanya (know-about). Ini pula alasan kenapa penelitian sosial bersifat bebas nilai, sedangkan penelitian hukum tidak bebas nilai.Perlukeseriusan dan kehatian-hatian memahami inti

tatanilai, melainkan sekedarmemandangnyasebagai fenomena perilaku sosial (social behavior). Cara pandang semacam ini berbeda dengan cara pandang jurist danpenstudi ilmu hukum yang memandang hukum sebagai tatanilai yang sifatnya idealabstrak dan pproporsional-sistematis. Nilai satu dan lain nilai saling kait tanpa ada pertentangansebagai kesatuan konsep dan pola-pola abstrak yang dapat dirasai secara nalar. Hukum, bagaimanapun, merupakan object materia ilmu sosial dan ilmu hukum. Namun begitu, object forma antara keduanyalah yang membedakan bagai-mana object materia itu diperlakukan atau dipandang.

${ }^{2}$ Yang dimaksud dengan "ranah praktis hukum" di sini adalah penelitian terhadap isu hukum dengan menemukan dan memberikan jawaban hukumnya di dalam peraturan legal atau sejauh ketentuan perundang-undangan yang berlaku. Penelitian praktis berkaitan penerapan hukum atas peristiwa hukum. 
gagasan penulisatas hakikat ilmu hukum di bab ini.Kata kuncinya adalah: ilmu hukum adalah ilmu tentang nilai. "Nilai berada di luar studi empiris (h. 18)."

Bab kedua membahas karakteristik penelitiandalam ilmu hukum.Sebenarnya, bab ini menjelaskan lebih lanjut dari bab pertama. Menelaah karakteristik penelitian dalam ilmuhukum-tentu saja dengan sendirinya juga menelaah hakikat ilmu hukum-dalam bab ini sejatinya menelaah ilmu hukum dalam tataran ontologi dan epitemologi keilmuan yang mana tidak bisa tidak menelisik ilmu hukum dalam frame filsafat ilmu. Memang, bab ini tidak mendedah ilmu hukum dalam ruas filsafat ilmu secara lebih mendalam-Anda sepertinya butuh beberapa referensi mengenai filsafat ilmu. Tujuannya agar kita tahu apa sihhakikat yang dipelajari dalamilmu hukum, batas-batas, objek yang dipelajari, dan fungsi dan tujuan dari hukum dan penelitian/kajiannya. Juga sekaligus memahami bedanya dengan disiplin di luar ilmu hukum.

Penelitian hukum merupakan suatu kegiatan know-how.... Hasil yang dicapai adalah untuk memberikan preskripsi mengenai apa yang seyogianya atas isu yang diajukan (h. 83). Bukan sekedar know-about.

Bab ketiga membicarakan isu hukum. Isu dalam tempo lain disebut permasalahan, objek, dan perkara. Isu adalah opo sing dijinggleng. Seperti dalam penelitian lainnya, isu dalam penelitian hukum adalah hal yangpokok. Isu/objek/permasalahan/problempe-nelitian hukum harus dipahami lebih dulu sebelum menetapkan metode/pendekatan; untuk menetapkan pendekatan apa yang harus digunakan, kita harus mafhum dahulu isu hukum itu di tataran mana dalam lapisan ilmu hukum. Isu dalam ranah praktiklitigasi hukum kadangjuga disebut "kasus hukum”, "peristiwa hukum”, "perkara hukum”, dan kadang "objek perkara”. Menurut beliau—saya kutip persis seperti kalimat subjudul buku—isu hukum adadi dalam 3 kelompok:"Isu Hukum dalam Dogmatik Hukum”, "Isu Hukum dalamTeori Hukum”, dan“Isu Hukum dalam Filsafat Hukum”.Perlu kejelian menangkap maksud kalimat subjudul. Keliru memahami, menimbulkan anggapan keliru bahwa setelah kata "dalam"itulah objek penelitian. Bukan. Meski bab ini berkaitan isu hukum,penulis tidak menunjuk langsung objek/isu penelitian hukum, tapimalah menunjuk pendekatannya,ini hal yang sekiranya patut diperjelas lagi.Macam-macam metode/pendekatan dalam penelitian hukum sendiri adalah yang dikupas di bab keempat.

Bab keempat berisi mengenai cara me-mecahkan isu/objek penelitian hukum. Bila menyangkut "cara", maka sama halnya kita bicara metode/pendekatan yang dipergunakan memecahkan isu hukum. Metode/pendekatan dalam penelitian hukum disebutkannyaadalahpendekatan peraturan perundang-undangan (statutes approach), pendekatan kasus (case[s] approach), pendekatan historis (historical approach), danpendekatan konsep-tual (concepttual approach).

Bab kelimamembahas mengenai sumber-sumber hukum. Bab ini oleh penulis diberi judul "Sumber-sumber Penelitian Hukum”, judul bab yang aneh. Menurut beliau,

sumber-sumber penelitian hukum dapat dibeda-kan menjadi sumber-sumber penelitian yang berupa bahan-bahan primer dan bahan-bahan hukum sekunder (h. 181).

Lanjutnya, bahan-bahan hukum primer adalah peraturan perundang-undangan dan putusan pengadilan "yang berkaitan dengan isu hukum yang dihadapi (h. 187)."Bahan-bahan hukum sekunder adalah buku-buku hukum, skripsi, tesis, dan disertasi hukum dan jurnal hukum. Selain itu, juga ada bahan-bahan nonhukum. Membacai judul dan isi bab ini, yaitu terkait istilah "bahan", tampaknya terjadi ketidak-konsitenan penjelasan jikamengingat uraian bab pertama dan kedua, yaitu penjelasan bahwa ilmu hukum terkaitvalues, 'nilai-nilai'. Bagaimana ceritanya ilmu hukum yang hakikatnya berkaitan nilai-nilai, seperti yang dikatakan beliaudi luar rumpun empiris, kemudian tiba-tiba muncul istilah bahan hukum? 
Bab keenam membahas hal-hal teknis bagi orang yang hendak melakukan penelitian/ kajian hukum. Bab ini utamanya bicara langkah-langkah teknis (yang jika dibacai, lagi-lagi, tampaknya terjadi bias dengan penjelasan beliau di bab pertama dan kedua).

Meski kurang sistematis, bab pertama dan kedua dalam menjelaskan hakikat penelitianhukum-yang tentu saja juga membahashakikat keilmuan hukum-dalam tataran ontologi dan epistimologi. Namun begitu, hakikat ilmu hukum bukan sejauh ontologi dan epistemologis saja, melainkan juga sampai pada tataran aksiologis. ${ }^{3}$ Bab ketiga, keempat, dan kelima lebih kepada pemahaman tekniskonseptualtentang bagaimana memahami objek/isu dan paradigma berpikir apa (metode/pendekatan) dalam memberikan jawaban hukumnya atau merumuskan kebenarannya, serta sumber hukum yang apa tepat untuk diacu.

\section{Catatan pinggir untuk buku}

Ada beberapa hal yang mengganggu pikiran ketika membaca dan merenungkan buku yangmenarik ini. Sepertinya, ada yang patut diselisik dan dieksplorasi lebih lanjut.

\section{Yang "patut diperjelas lagi": ekplorasi lebih jauh}

"Ilmu hukum merupakan studi tentang hukum (h. 44)".Itu benar. Lalu, apa itu hukum? Yang dimaksud hukum hari ini adalah peraturan yang dibuat suatu otoritas sah yang berlaku disatu yuridiksinya, yangbisa saja berbeda fitur peraturan dan bisa saja berbeda format/sistemnya dengan yuridiksi lain dan bilamana subtansi aturan dirasa berseberangan dengan sumber-sumber hukum material/subtantif dan asas-asas hukum, dewasa ini di banyak negara dapat dimohon-kan pengujiannya ke lembaga hukum yang berwenang menguji itu.

Sebagaimana beliau kutip,Gisjsels men-jelaskan ilmu hukum dalam kerangka atau tataran epistememenyatakan bahwa lapisan ilmu hukum adalah dogmatik, teori, dan filsafat hukum(periksa halaman 45). Jika kita adaptasi menjadi tabel adalah seperti berikut.

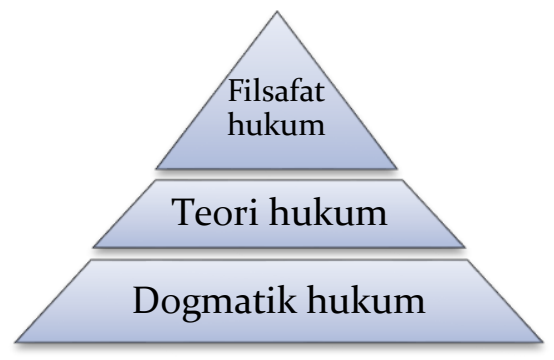

Tabel 1.lapisan hukum menurut Jan Gisjsels.

Jika dikaitkan dengan penjelasan Gisjsels tadi dalam konteks format/sistem hukum legalnegara Indonesia hari inimerujuk pada lapisan dogmatik hukum. Penjelasan semacam ini sebangun dengan pernyataan Rahardjo ${ }^{4}$ bahwa peraturan perundang-undangan me- rupakan salah satu media membadankan norma hukum.

Dalam penjelasan beliau di buku yang kita review ini menyatakan bahwa isu hukum ada di dalam 3 kelompok:"Isu Hukum dalam Dogmatik Hukum”, "Isu Hukum dalamTeori Hukum”, dan“Isu Hukum dalam Filsafat Hukum”.Sepertinya, beliau merumuskan subjudul-subjudulini terjebak penjelasan

\footnotetext{
${ }^{3}$ Dominikus Rato, 2014, Filsafat Hukum, LaksBang Justi-cia, Surabaya, h. 56.

${ }^{4}$ Satjipto Rahardjo, 2012, Ilmu Hukum, Citra Aditya Bakti, Bandung, h. 41.
} 
Gisjsels tentang hakikat ilmu hukum yang sejatinya menjelaskan dalam tataran episteme. Tidak salah. Memang apayang dipelajari ilmu hukum dalam tataran episteme berkutat pada 3 lapisan tersebut. Namun begitu, jangan melupakan tataran aksiologi.Dalam tataran ini, "hukum pada akhirnya harus diarahkan kepada praktik hukum." PPraktik berkaitan kegunaan. Tataran aksiologi ini sepertinyaterlewatkan atau sepertinya yang menjadikan gamang penulis buku,sehingga merumuskan subjudul-subjudul semacam itu. ${ }^{6} \mathrm{Hemat}$ pribadi, perumusan dan penjelasan semacam itu akan membingungkan pembaca buku. Sekali lagi, ilmu hukum dalam tataran aksiologi adalah produk hukum-siap-pakai yangmengemban tugas dan untuk dapat digunakan dan dapat diterapkan dalam masyarakat.

Jadi,objek/isu/permasalahan/perkarayang dikaji dalam penelitian hukum jika diadaptasi menjaditabelakan tampak seperti berikut.

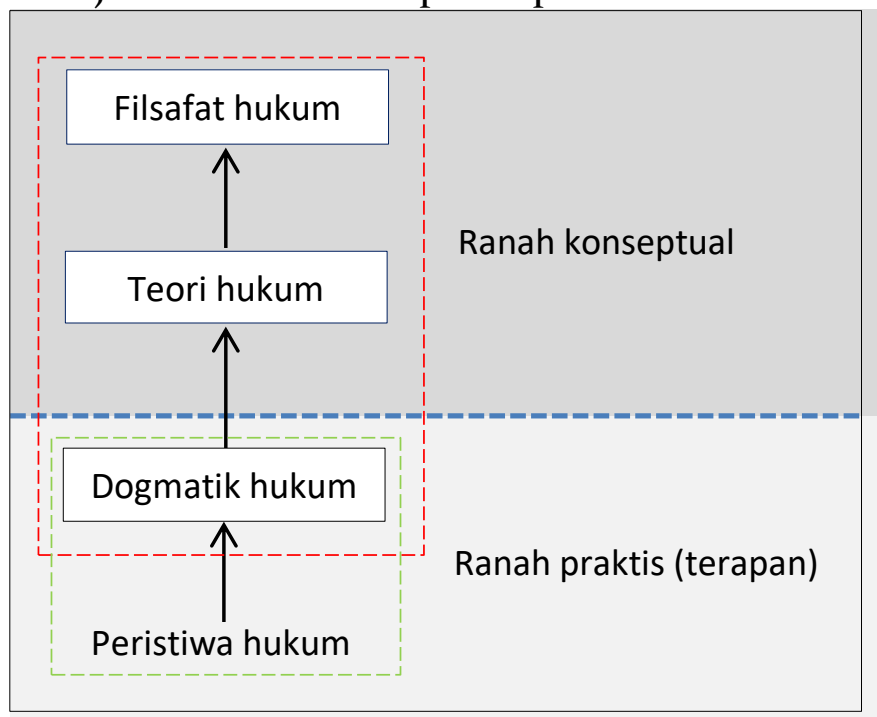

Tabel 2. Yang ada dibawah setiap ekor anak panah adalah objek/isu penelitian hukum dan yang ada diatas setiap kepala anak panah adalah metode/pendekatan dalam pemecahan isu/objek penelitian hukum. Yang di dalam garis merah putus-putus ialah tataran ontologi dan epsitemologi ilmu hukum. Yang ada di dalam garis hijau putus-putus adalah tataran aksiologi ilmu hukum. Garis biru putus-putus adalah demarkasi antara kedua ranah ilmu hukum: ranah praktis/terapan dan ranah konseptual.

Patutdigarisbawahi, terkait macam-macam pendekatan yang diajukan buku ini tidak menjelaskan secara sistematik dan spesifik bagaimana alurnya bila dikaitkan dengan macam-macam objek penelitian hukum, lapisan ilmu hukum yang dijelaskan, dan format/sistem hukumnya: jika objeknya misalkan A, maka pendekatannya apa; atau jika objeknya B, maka pendekatannya yang apa. Pola pendekatandalam tabeldi atas hanya bisa dipergunakan ketika objek/isu penelitian hukumnya tidak bisa tidak harus menggunakan pendekatanperaturan per-undang-undangan, atau objeknya tidak bisa tidak harusdidekati secara konseptual. Dengan kata lain, jika objeknya adalah peristiwa hukum, maka pendekatannya tidak bisa tidak-dengan mengingat format hukum formal Indonesia-harus dengan pendekatandogmatik hukum (peraturan-peraturan legal atau perundang-undangan yang bertalian dengan peristiwa hukum itu). Analoginya, peristiwa hukum ibarat pasien, peraturan legal ibarat pisau bedah, dan peneliti ibarat dokter. Bila yang menjadi objek/isu/permasalahan/perkara hukumnya

\footnotetext{
${ }^{5}$ Philipus Hadjon dan Tatiek Sri Djatmiati, 2016, Argu-mentasi Hukum, Gadjah Mada University Press, Yogyakarta, h. 10.

${ }^{6}$ Patut diakui, penulis dalam penjelasanmasing-masing subbab tadi secara umum, jika direnungkan, memang menyatakan ruang lingkup pendekatan dogmatik hukum (pendekatan perundang-undangan) dimungkinkan ketikaisu hukumnya adalah fenomena/peristiwa hukum yang terjadi di masyarakat, dikatakannya dengan istilah "memberatkan aspek praktis ilmu hukum" (periksa halaman 103). Adapun ruang lingkup pendekatan konsep-tual, menurut penjelasan beliau, “... diperlukan bagi mereka yang ingin mengembangkan suatu bidang kajian hukum tertentu" (periksa halaman 112).
} 
adalah konsistensi dan/atau kesesuaian antarpasal dalam satu peraturan atau antar peraturan baik secara horizontal atau vertikal, maka tidak bisa tidak metode/pendekatan yang diadopsi adalah konseptual, yaitu usaha mendekonstruksinya kembali pada teori hukum, upaya “... mengkaji kondisi intrinsik aturan hukum [perundang-undangan] guna mengetahui gagasan-gagasan mendasar hukum, bersifat universal, umum dengan menggunakan kekuatan logika (h. 42).”Analoginya, bila yang kita dipertanyakan, misalnya, ada-tidaknya konsistensi antarpasal dalam satu peraturan atau antar peraturan tadi, ituibarat si pasien. Sementara teori-teori yang kita pilih dan gunakan ibarat alat/pisau bedah, dan peneliti ibarat dokter ahli. Jika "si pasien" adalah teori dan "pisau bedah" adalah berpikir kritis (berfilsafat), maka watak penelitian/kajian hukum tataran ini adalah kontemplatif dan subjektifrasional,seperti halnya kerja berfilsafat pada umumnya. Kajian hukum macam ini sebenarnya adalah kajian filsafatpada umumnya.

\section{Untuk "judul bab yang aneh":sumber hukum atau bahan hukum?}

Memang hakikat ilmu hukum hingga sekarang ini masih menjadi perdebatan. Sebagian pihak memandang ilmu hukum termasuk inter-disipliner. ${ }^{7}$ Ada yang memandang sebagai rumpun sosialper se rumpun ilmu empiris, misalnya Soekanto dan Mamudji. Lainnya, memandang bahwa ilmu hukum adalah ilmu yang objeknya adalah nilai, cara pandang inilah yang diamini beliau, penulis buku yang di-review ini.

Dalam penjelasan di bab pertama dan kedua jika direnungkan, beliau menjelaskan ilmu hukum berkaitan values, yaitu normayang sarat dengan muatan nilai-nilai dan itu menempatkan ilmu hukum berwatak normatif dan berada di luar rumpun empiris. Karena itu, beliau tegas menyatakan, "asumsi bahwa suatu metode penelitian dapat digunakan untuk semua bidang ilmu tidak dapat diterima (h. 5)."

Ketika mempelajari ilmu hukum di ruang kuliah, kita diajarkan bahwa sumber hukum diklasifikasikan ke dua kelompok: sumber hukum materiil dan sumber hukum formil. Pembedaan ini pertama kali dikenalkan oleh Salmond pada 1902, sementara orang yang pertama kali mengajak untukmemberi atensi terkait ambiguitas penggunaan istilah "sumber hukum" adalah Austin dan ia orang yang mencoba memetakan kajian ini, akan tetapi tidak memuaskan. ${ }^{8}$ Yang pertamaadalah sumber hukum material (a material sources of law)dan yang kedua adalah sumber hukum formal (a formal sources of law). Sumber yang pertama ini ruang lingkupnya begitu luas, yaitu apa saja yang menjadi "bahan mentah" atau "asal muasalnya hukum" atau "tempat diperolehnyabahan hukum untuk sumber hukum formal". Sumber hukum material adalah "[a things] determining the content of legal precept."9 Terjemah bebasnya, hal-hal yang menentukan isi sebuah peraturan legal (hukum formal).Sumber yang kedua dapat dirumuskansebagai tindakan penabalan atau pengesahan otoritas yang sahatas sumber hukum yang disebut pertama tadi. ${ }^{10}$ Dalam format atau sistem hukum RomanoGermanic, sumber hukum yang kedua ini adalahperundang-undangan.Karenanya, bila membicarakan 2 sumber hukum tadi dalam konteks hukum Indonesia, maka hanya perundang-undangan itulah apa yang disebut sumber hukum formal. Hanya undang-undang yang bersifat mengikat.

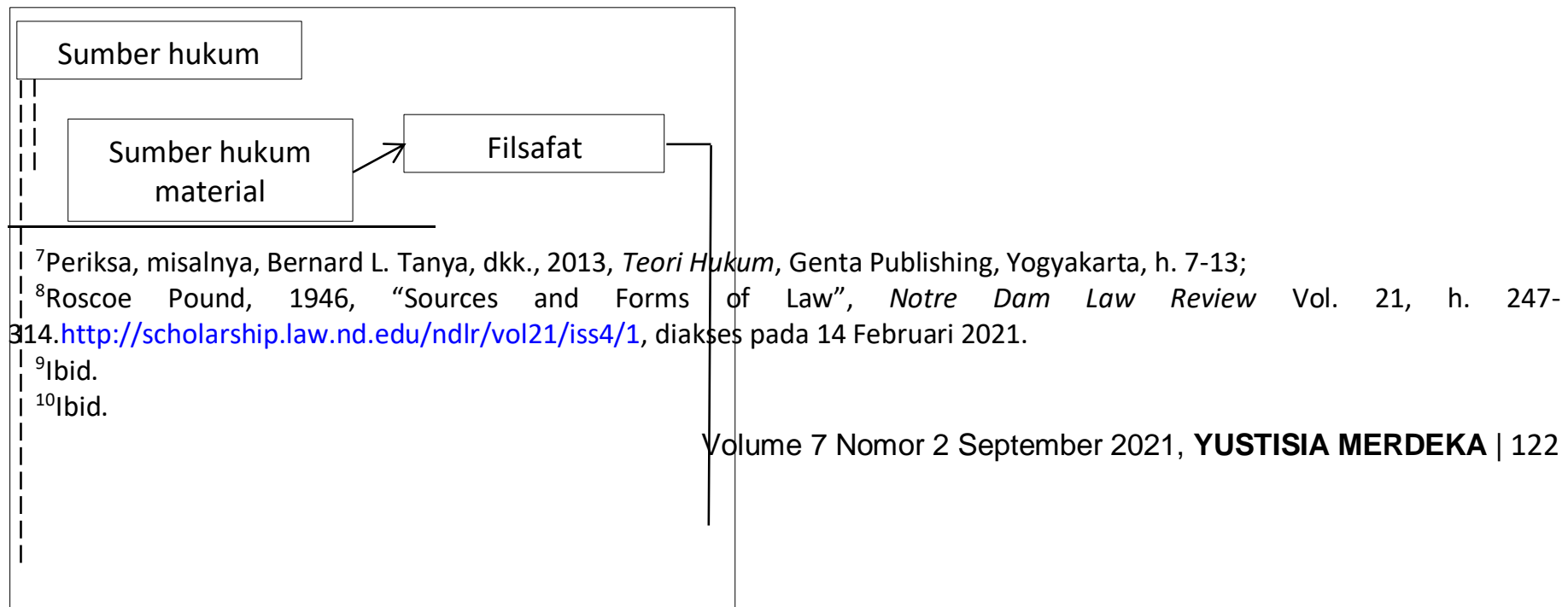




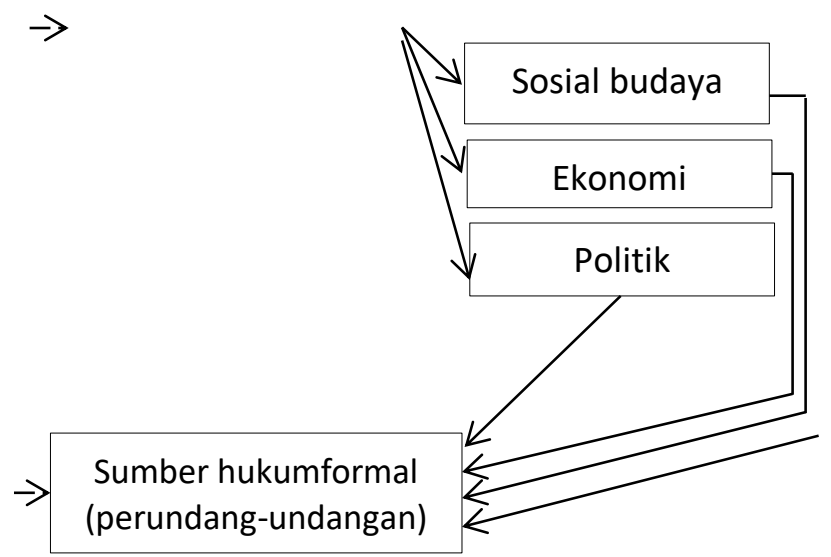

Tabel 3.Bagan sumber hukum material dan formal hukum nasional Indonesia. Sumber-sumber hukum material di atas adalah sumber-sumber hukum yang menjadi rujukan pembuatan sumber hukum formal (perundang-undang) nasional dalam kerja legislasi. Bukan hal yang tidak mungkin, di antara sumber hukum material tadi akan saling bertolak atau saling mengisi dan memengaruhi dalam proses legislasi.

Berangkat dari pemahaman di atas, maka kita dapat simpulkan bahwa apa yang beliau katakan terkait klasifikasi“sumber-sumber penelitian hukum”menjadi 2 kategori,yaitu bahan hukum primer dan bahan hukum sekunder, hemat saya pribadi,adalah istilah yangtidak tepat sama sekali. Lebihlebih, mengingat pernyataan beliau bahwa studi hukum di luar rumpun empiris. Kata "bahan" di sini jika membacai penjelasan beliau identik dengan sesuatu yang material atau kebendaan atau berobjek fisis, padahalobjek materia ilmu hukum sebagaimana penjelasan beliau adalah values dan itu bukan objek empiris atau terindra. Pun tidak selamanya peraturan perundang-undangan berkedudukan sebagai "bahan hukum primer". Di dalam penelitian dengan pendekatan konseptual, konsistensi pasal dalam peraturan perundang-undangan adalah isu/objek yang ditelaah dengan pisau bedah-nya adalah teori. Artinya, perundang-undangan dalam penelitian tersebut adalah ibarat si pasien, sebagai objek yang diteliti. Karenanya, juga tidaklah tepat istilah bahan hukum primer dan bahan hukumsekunder seperti beliau jelaskan. Berangkat dari uraian di atas, istilah yang tepat bukanlah "bahan hukum", tetapiyang tepat adalah "sumber hukum".Apalagi istilah data primer dan data sekunder, sama sekali tidak merepresentasi-kan hakikat ilmu hukumsui generisnormatif.

\section{Pendekatan perundang-undangan tetap butuh sumber hukum doktrinal}

Sumber hukum doktrinal adalah segala sumber hukum yang dinyatakan oleh ahli hukum (jurist), baik itu disampaikan secara oral atau tertulis. Karenanya ada adagiumius comminis ius doctorum. Selain ada perundang-undangan, traktat, kebiasaan, dan yuris-prudensi yang dikenal dalam ajaran ilmu hukum terkait sumber hukum formal, doktrindikategorikan sebagai sumber hukum formal. Namun, dengan mengingat format/sistem hukum nasional, tidak semua macam sumber hukum formal tadi layak diacu dan memiliki kekuatan megikat.

Terkait penelitian ranah praktis hukum, yaitu penelitian hukum dengan pendekatan perundangundangan, doktrin masihlah tetap perlu diacu, kedudukannya sebagai penopang peraturan perundang-undangan (sumber hukum yang sah mengikat). Fungsinyamenjadi rujukan ketika penjelasan suatu maksud pasal masih belum terang.Sifat sumber hukum ini tidak mengikat dalam penelitian tataran penelitian praktis, baik dalam penelitian akademik maupun dalam praktik hukum. Misalnya, penjelasan strafbaar feit yang mana dalam Wetboek van Straafrecth (WvS), ataupun dalam versi terjemahannya disebut KUHP, tidak diketemukan pengertian yuridis-definitif dari istilah tersebut. Muncul-lah beberapa pendapat ahli hukum (jurist) pidana nasional, baik dalam usaha menerjemahkan secara tepat arti harfiahnya atau dengan maksud membuat terang maknanya dalam ilmu hukum pidana. Dalam praktik hukum, doktrin atau pendapat ahli hukum dipergunakan sebagai 
penguat putusan hakim. Namun begitu, sekali lagi, ia secara hukum tidak mengikat. Sekedar penopang sumber hukum yang sah diacu.

\section{Penutup}

Buku ini memberikan penjelasan lumayan gamblang terkait hakikatilmu hukum dan penelitiannya. Buku ini rasa-rasanya sedang melakukan pemberontakan atau melayangkan gugatan terhadap alur berpikiratau pe-mahaman quoatas ilmu hukum yang berkembang di Indonesia.Tidak dipungkiri, buku ini sangat berpengaruh. Bukti bahwa buku ini memberi pengaruh dalam khasanah ilmu hukum dan penelitiannya di ruang akademik di Indonesia adalah mudah di-jumpainya artikel-artikel dan tugas-tugas akhir akademisi hukum yang mengutipnya.Namun begitu, sayangnya, ada saja yang mengutipsecara serampangan,cerry picking, tanpa memahami alur berpikir dan pendapatpenulis terhadap hukum. Ciri paling mudah dikenali itu adalah mencomot satu pendapat hukum seorang ahli hukum (doctrine), baik yang disampaikan dalam medium tulisan dan lainnya, sekaligus mengutip pendapat yang lain yang jika dipahami seksama berbeda pendapat dan pemahaman dengan yang pertama disitasi.

Sebenarnya, masih banyak hal dalam penjelasan buku yang menyediakan kita "ruang tembak" untuk mempertanyakan lebih jauh, misalnya, apakah pendekatan kesejarah-an (historical approach) termasuk pendekatan absah dalam hukum yang notabene sui generisnormatif, sebagaimana yang beliau sendiri amini. Atau, mempertanyakan lebih jauh terkait nilai guna apa yang ingin dicapaipersis seperti tertulis di buku-“case approach", bukan "cases approach"dengan mengingat format/sistem hukum Indonesia. Pendekatan case[s] approcah pendekatan dijabarkan beliau adalah penelitian yang me-nelaah putusan-putusan hakim yang sudah incracht terhadap kasus hukum yang memiliki keserupaan dengan kasus-kasus itu dengan mengingat format hukum Indonesia. Namun, ulasan di sini memang sengaja tidak me-nyinggung hal tersebut.

Sebagai penutup, pendapat pribadi, kata penelitian (research) umumnya di kesadaran kita dipahami sebagai sebuah kegiatan yang utamanya melibatkan kegiatan fisik yang aktif (utamanya tampak dalam penelitian sosial): terjun ke lapangan dan mengumpulkan data ke sana kemari. Atau, dalam ilmu-ilmu ekperimental terbersit di pikiran kita tentang laboratorium, eksperimen, menetapkan dan bilamana diperlukan mengubah variabel, mengukur, dan mencatat hasil eksperimen penelitian ke bentuk angka-angka. Penelitian hukum sejatinya bukanresearch-sebenar-benarnyaresearch, melainkan suatu usaha menyusun argumentasi hukum secara logis atas isu/objekpenelitian hukum berdasar sumber hukumnya.Hakikat penelitian hukum adalah rangkaian kegiatan yang menekankan proses berpikir kritis dan analitis (inquiry method) guna menemukan jawaban atas permasalahan yang dihadapi itu. Aktivitas peneliti lebih banyak tersita untuk merenung dan berpikir analitis. Itu pulakenapa pe-nelitian hukum sejatinyaarmchair discipline, penelitian yangbisa dikerjakan denganduduk-duduk di atas kursi. Oleh karenanya, istilah untuk "penelitian hukum" sebaiknya diganti dengan istilah "kajian hukum" atau "telaah hukum”.Sekiranya juga pemberian judulbuku ini. Seyogyanya. []

\section{Literatur pendukung dan pembanding:}

Bernard L. Tanya, dkk., 2013, Teori Hukum, Genta Publishing, Yogyakarta.

Dominikus Rato, 2014,Filsafat Hukum, LaksBang Justicia, Surabaya.

Philipus Hadjon dan Tatiek Sri Djatmiati, 2016, Argumentasi Hukum, Gadjah Mada University Press, Yogyakarta. 
Roscoe Pound, 1946, "Sources and Forms of Law", Notre Dam Law Review Vol. 21, h. 247314.http://scholarship.law.nd.edu/ndlr/vol21/iss4/1.

Satjipto Rahardjo, 2012, Ilmu Hukum, Citra Aditya Bakti, Bandung.

Soerjono Soekanto dan Sri Mamudji, 2017,Penelitian Hukum Normatif, RajaGrafindo Persada, Jakarta. 